\title{
A defesa judicial dos direitos sociais prestacionais a partir da teoria dos direitos humanos de Amartya Sen*
}

\author{
Daniel dos Santos Rodrigues \\ Bacharel em Direito pela UFG. Pós-Graduado em Direito Processual. Técnico Judiciário do TRE-GO.
}

\begin{abstract}
Resumo: Este artigo estuda, a partir do referencial da teoria dos direitos humanos de Amartya Sen, os obstáculos e possibilidades à defesa judicial dos direitos sociais prestacionais. Observa que a realização destes direitos enfrenta três ordens principais de problemas: 1) filosófico, pois teorias de justiça parciais contestam sua fundamentalidade; 2) jurídico-político, uma vez que, por envolver complexas prestações normativas e materiais, assim como argumentos de natureza ética e política, a realização dos direitos sociais prestacionais pela jurisdição poderia violar o princípio da separação dos poderes; 3) processual, porquanto ainda são poucos os instrumentos e as experiências jurisprudenciais voltados à sua efetivação. Conclui-se que, não obstante tais dificuldades, a realização dos direitos sociais prestacionais é possível, desde que se compreenda que os direitos fundamentais são reconhecidos a partir de uma conjugação entre juízos éticos plurais e deliberação democrática. De outra parte, utilizando-se de instrumentos interpretativos, argumentativos e éticos mais amplos, tais como o direito construtivo de Dworkin e a democracia deliberativa de Habermas, bem como o princípio do mínimo existencial, o judiciário estaria apto a defender os direitos sociais prestacionais sem violar o princípio da separação dos poderes. Por fim, tem-se que, valendo-se dos conceitos de mínimo existencial e de metadireitos, a defesa judicial dos direitos sociais prestacionais pode realizar-se através de alguns instrumentos processuais atuais, desde que devidamente utilizados de acordo o princípio fundamental da tutela jurisdicional efetiva.
\end{abstract}

Palavras-chave: Direitos fundamentais. Direitos sociais prestacionais. Discricionariedade administrativa. Efetividade dos direitos. Violação da separação dos poderes.

\section{Introdução}

Apesar da prescrição dos direitos sociais em várias cartas constitucionais e em tratados internacionais de direitos humanos ao redor do mundo, a baixa efetividade destes direitos ainda é persistente, principalmente em países periféricos como o Brasil, fato que acaba por frustrar expectativas sociais e contestar o próprio Estado Democrático de Direito.

Como os direitos sociais constituem-se em importantes instrumentos de combate às mazelas sociais, como baixa distribuição de renda, fome, etc., pesquisar formas de torná-los efetivos é tarefa premente.

\footnotetext{
* Artigo baseado no trabalho de conclusão de curso intitulado "A Contribuição da Teoria dos Direitos Humanos de Amartya Sen na Sindicabilidade Jurisdicional dos Direitos Sociais Prestacionais" e apresentado na PósGraduação "Direito Processual: Grandes Transformações" ministrado pela Rede LFG e UNAMA.
} 
Sendo assim, como o próprio título já antecipa, o objetivo principal deste trabalho é estudar, a partir da teoria de direitos humanos do economista indiano Amartya Sen, o difícil tema da possibilidade de se garantir judicialmente os direitos sociais prestacionais.

Nestes termos, será visto na primeira parte do estudo que, antes de tudo, o problema da efetividade dos direitos sociais passa por obstáculos de ordem filosófica, porquanto muitos relutam em reconhecer estes direitos como fundamentais. Neste momento três assuntos serão relevantes: 1) a divisão que ainda existe entre direitos liberais e sociais, a qual denuncia o fato de que a resistência a estes últimos possui como causa juízos éticos parciais, fundados em concepções de liberdade muito restritas; 2) saber o que faz um direito ser reconhecido como fundamental; e 3) quais são as obrigações que os direitos fundamentais concebem. Complementando esta parte, será discutido também o problema da possibilidade de algum direito ser plenamente auto-aplicável, uma vez que muitos autores entendem que todo direito fundamental deve possuir o atributo da auto-aplicabilidade. Para o desenvolvimento desses assuntos, o pensamento de Sen traz grandes contribuições, pois, segundo este autor, os direitos humanos possuem algumas importantes características, a saber: 1) vinculam-se intrinsecamente com as liberdades reais (e não meramente formais) que formam o conteúdo desses direitos; 2) são demandas éticas abertas ao pluralismo e à discussão pública, de maneira que sua fundamentalidade só pode ser posta à prova pela própria sociedade; e 3) encerram os mais variados tipos de obrigações, tanto negativas quanto positivas, fato esse que contesta a possibilidade de um direito ser totalmente auto-aplicável.

$\mathrm{Na}$ segunda parte do trabalho, veremos as dificuldades e possibilidades da sindicabilidade judicial dos direitos sociais, momento que será defendida a tese de que, utilizando-se do conceito do mínimo existencial - principalmente a partir do contributo do conceito de liberdade de Sen —, do método construtivo de Dworkin e da democracia deliberativa de Habermas, é possível encontrar mecanismos jurídicos para defender judicialmente estes direitos sem se violar o princípio da separação dos poderes. É que, se os direitos sociais são verdadeiros direitos, faz-se premente e necessária a busca de mecanismos jurídicos que tornem tais direitos efetivos e reais, uma vez que a tentação em utilizar-se de argumentos puramente ideológicos ou políticos sempre se apresenta neste debate. Reforçando tal alerta, tem-se que um dos maiores desafios da defesa judicial destes direitos é justamente o perigo de invasão da esfera de discricionariedade das funções eminentemente políticas do Estado, quais sejam, a legislativa e a executiva. Sim, porque, por envolver complexas prestações materiais e normativas, bem como 
ponderações entre inúmeros valores e princípios jurídicos, a realização dos direitos sociais geralmente é deixada a cargo da política.

Para a última parte, ficaram reservadas as discussões em torno dos aspectos processuais do tema, momento em que serão expostos alguns rascunhos a respeito de como defender judicialmente os direitos sociais prestacionais. Neste passo serão debatidas as propostas do mínimo existencial como direito subjetivo individual definitivo, i.e., como possibilidade de ser defendido judicialmente sem sofrer restrição pela reserva do possível ou pelo princípio da separação dos poderes, e a de meta-direitos de Sen, pela qual poder-se-á cobrar do Estado a realização de políticas públicas voltadas à concretização progressiva dos direitos sociais prestacionais.

\section{Fundamentalidade dos direitos sociais prestacionais}

\subsection{Teorias de justiça e a fundamentalidade dos direitos}

Antes de ser um problema jurídico (o qual absorve diversas discussões, notadamente sobre hermenêutica e processualística, temas que serão melhor tratados nas seções seguintes), ${ }^{1}$ a questão da realização dos direitos sociais prestacionais é um problema filosófico, ${ }^{2}$ uma vez que muitos críticos não aceitam tais direitos como fundamentais. Aqui dois assuntos conexos são importantes: 1) a divisão ainda existente entre direitos liberais e sociais, cuja causa deita razão no conflito (mal resolvido) entre diferentes teorias de justiça; ${ }^{3}$ e 2) saber o que faz um direito ser fundamental.

Sobre o primeiro ponto - sumamente importante para entender o segundo - , interessante notar que várias correntes jusfilosóficas guardam ideais específicos de justiça como critérios de admissão da fundamentalidade dos direitos. Assim as concepções liberais (incluindo as libertárias) e as socialistas foram as que mais influenciaram a teoria dos direitos fundamentais (ou humanos, na perspectiva internacional) no decorrer da história do constitucionalismo moderno: ${ }^{4}$ a grosso modo, as primeiras conceberam os direitos de $1^{\mathrm{a}}$ dimensão (ou direitos liberais), as segundas os direitos de $2^{\mathrm{a}}$ dimensão (ou direitos sociais).

Para as correntes liberais clássicas, a idéia de direitos fundamentais encontrase presente na garantia de 'não ingerência' (do Estado e de outros particulares)

Cf. GOUVÊA. O controle judicial das omissões administrativas: novas perspectivas de implementação dos direitos prestacionais, p. 140.

2 É certo que a presente questão envolve outros temas fora do direito, tais como política, economia e sociologia, os quais, em seus aspectos mais verticais, não são objetos específicos deste estudo.

3 Cf. GOUVÊA. O controle..., p. 345; Cf. SEN. Elements of a Theory of Human Rights, p. 318.

${ }^{4}$ Cf. BONAVIDES. A teoria dos direitos fundamentais, p. 562-565; Cf. VIZARD. The Contributions of Professor Amartya Sen in the Field of Human Rights, p. 7. 
sobre a esfera de liberdade do indivíduo. ${ }^{5}$ Em reforço a esta tese (não ingerência) edificaram-se as doutrinas libertárias, exacerbando como critério único de justiça o respeito à 'condição de universalização' (condition of universalitazion), princípio lógico que sustenta que os únicos direitos possíveis são aqueles que prescrevem deveres independentemente de conseqüências (end-independent), i.e., que todos devem respeitar sem qualquer exceção (universal obligations) ${ }^{6}$

Em contraposição ao liberalismo (e, evidentemente, ao libertarismo), as correntes socialistas dão ênfase à idéia de que os direitos devem garantir de fato a liberdade do indivíduo, sendo insuficiente uma juridicidade que apenas declare que um sujeito é igual e livre sem verificar se realmente ele goza deste status.

Muitos dos críticos de hoje aos direitos sociais parecem abraçar a concepção formalista liberal dos direitos fundamentais apresentada acima, uma vez que admitem como fundamentais apenas os direitos de $1^{\mathrm{a}}$ dimensão. Diz-se que os direitos liberais possuem uma justificação existencial imediata, a qual ausente nos direitos sociais, pois estes dependem, para sua realização, da inserção do indivíduo na sociedade. ${ }^{7}$ Entre os autores estrangeiros, destaca-se a posição de Böckenförde, para o qual os direitos sociais não passam de direitos relativos, pois não podem ser estendidos a todos sem algum tipo de avaliação fática e progressividade de prestação. ${ }^{8}$

Entre os autores nacionais, Torres segue linha parecida quando afirma que a 'tese da indivisibilidade' dos direitos fundamentais, qual concebe os direitos sociais fundamentais como são os liberais,

chega a alguns impasses: não consegue resolver o problema da eficácia dos tais direitos fundamentais sociais sem a intermediação do legislador; banaliza a temática dos direitos da liberdade sem fortalecer a dos direitos da justiça; apóia-se na idéia de "justiça social”, que postula a distribuição da riqueza social entre as classes, mas não leva à adjudicação de parcelas dessa riqueza a indivíduos concretos; tenta substituir as políticas públicas pela subsunção no processo judicial, atitude típica do bacharelismo; amortece a dimensão reivindicatória da cidadania; busca, enfim, a própria quadratura do círculo. ${ }^{9}$ (itálico no original)

\footnotetext{
Cf. SARLET. A eficácia dos direitos fundamentais, p. 181.

Cf. SEN. Desenvolvimento como liberdade, p. 86; Cf. VIZARD. Op. cit., p. 7.

Cf. GOUVÊA. Balizamentos da discricionariedade administrativa na implementação dos direitos econômicos, sociais e culturais, p. 323-324. Gouvêa apresenta assim o argumento: "...os bens sobre os quais versam os direitos de primeira geração já são detidos pelos seus titulares como prerrogativas inerentes à pessoa considerada em si mesma — possuem, portanto, uma justificação existencial imediata —, ao passo em que os direitos sociais relacionam-se a bens cuja possibilidade de aquisição ou cujo valor depende da inserção da pessoa humana na sociedade" (p. 323-324).

8 Cf. GOUVÊA. Balizamentos..., Op. cit., p. 363; Cf. TORRES. O mínimo existencial, os direitos sociais e a reserva do possivel, p. 452-453.

9 TORRES. Op. cit., p. 454. Interessante notar que, apesar de dizer que os direitos sociais não são direitos fundamentais, Torres sustenta algumas posições avançadas, como a criação, no Brasil, de instrumento
} 
Vê-se que, ao separar direitos sociais dos direitos liberais, Torres quer distinguir liberdade de justiça, como sendo esta o meio para a primeira. Porém tal separação, em termos substanciais, realmente demonstra-se difícil de fazer.

Mas o que constitui exatamente estes direitos de liberdade? Seriam somente as condições formais / procedimentais, como expostas no libertarismo, ou também estão incluídas condições materiais mínimas de fruição dessas liberdades? Torres comenta que o direito ao mínimo existencial somente é um direito fundamental enquanto assegura, em última análise, a fruição dos direitos liberais, ${ }^{10}$ mas discutir a realização deste mínimo não é uma questão de justiça, visto ser um meio claro para a liberdade?

Nesse ponto a teoria dos direitos humanos de Amartya Sen demonstra grande relevância, pois o seu principal fundamento é justamente o significado da liberdade que forma a essência desses direitos. ${ }^{11}$ Ao criticar a base informacional (as variáveis relevantes) da teoria da justiça de John Rawls, o economista indiano argumenta que os bens primários (basicamente os meios necessários para uma existência livre e digna, os quais centram-se nas coisas) ${ }^{12}$ na teoria do filósofo americano representam um espectro muito limitado de condições necessárias para a liberdade, ${ }^{13}$ porquanto, para Sen, as oportunidades substantivas (centradas nas pessoas) também devem ser levadas conta.

Um exemplo do próprio Sen pode ajudar a iluminar a questão. Imaginemos duas pessoas com o mesmo conjunto de bens, sejam esses de qualquer tipo (recursos financeiros, bens in natura, etc.). Agora imaginemos que uma delas é portadora de alguma necessidade especial, por razão de uma deficiência qualquer. Qual delas detém maiores chances de fruição de liberdade? Considerando apenas as variáveis aqui expostas, percebe-se que a pessoa portadora de necessidade especial encontra-se em desvantagem em relação à que não possui qualquer limitação, ${ }^{14}$ o que fatalmente afetará o grau de fruição de liberdade.

Note-se que a teoria dos direitos humanos de Sen vincula-se a uma perspectiva bem ampla de liberdade, cujo conceito, calcado nas oportunidades reais (capabilities) de um indivíduo para levar uma vida digna e livre, ${ }^{15}$ ultrapassa

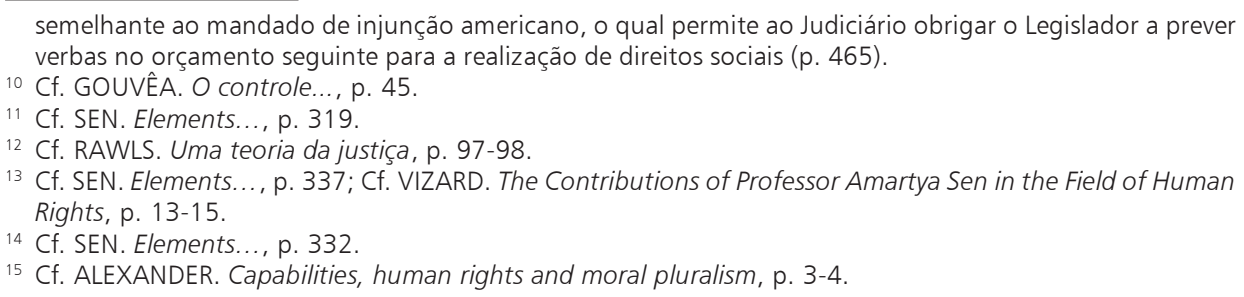


muito o conceito liberal (e sem a eliminação das liberdades formais empreendida pelo socialismo real), representando que uma separação lógica entre justiça e liberdade só seria possível considerando esta última em termos meramente formais. Em outras palavras, há uma clara indicação de que a concepção de uma teoria da justiça necessariamente influencia uma concepção de liberdade, e vice-versa. ${ }^{16}$

Cumpre observar que, mesmo uma concepção puramente procedimental de direitos — como a libertária o é — constitui, em si mesma, um ideal de justiça. ${ }^{17}$ Como diferentes ideais de justiça invariavelmente entram em conflito, nada diz que os direitos que cada um defende seguiriam caminho diferente. Em outros termos, para além da realização de uma liberdade formal, é possível perceber pontos de tensão entre os direitos sociais e liberais. Cabe, em essência, a pergunta: até que ponto podemos ir para garantir a liberdade real sem ofender a regra de não ingerência da liberdade formal ${ }^{18}$ É possível encontrar algum equilíbrio? Mais adiante será visto que o mínimo existencial talvez seja uma resposta para essas perguntas. Porém, o que é importante perceber, por enquanto, é que um direito não pode ser considerado fundamental somente a partir de uma concepção isolada de justiça. Sendo o liberalismo apenas uma dentre várias concepções de justiça, nada nos leva a crer que ele seria o único ideal a dizer quais direitos são fundamentais e quais não são, o que nos conduz à questão sobre o que faz, de fato, um direito ser fundamental.

Ato contínuo, somente nos últimos anos a teoria jurídica vem conseguindo uma solução mais satisfatória para a questão da fundamentalidade dos direitos. Após a insuficiência do apelo metafísico das correntes jusnaturalistas e do vazio moral lançado pelas vias positivistas radicais, a doutrina jurídica do pós-guerra foi obrigada a rever os fundamentos da ordem jurídica, de maneira a legitimá-la em bases morais e políticas mais sólidas. Os ideais de Kant e Rousseau tornaramse os novos pilares do direito moderno, da era dos direitos: do primeiro deriva a tradição racional-transcendente dos direitos humanos calcada na razão; do segundo origina o fundamento político-consensual, firmado na soberania popular. ${ }^{19}$

Construída sobre a constatação kantiana da insuficiência da mente humana em apreender as coisas em si mesmas e a partir da identificação da linguagem

\footnotetext{
${ }_{16}$ Cf. SEN. Desenvolvimento..., p. 76.

17 Cf. MACEDO JÚNIOR. Ação Civil pública, o direito social e os princípios, p. 294-299. Particularmente relevante, nesse texto, é o paralelo que traça o autor entre o direito liberal e o direito social. Diz Macedo Júnior que "[o] direito liberal clássico, baseado na noção de troca, é substituído pela noção de acordos de solidariedade, ancorados na idéia de justa distribuição ou eqüitativa alocação dos ônus e lucros sociais" (p. 294).

${ }^{18}$ Cf. SEN. Desenvolvimento..., p. 86. Nesta passagem, interessante a observação que faz Sen a respeito da possibilidade de uma teoria puramente procedimental dos direitos fundamentais ser catastrófica para os indivíduos sem sequer violar nenhum direito liberal negativo.

${ }^{19}$ Cf. GOUVÊA. O controle..., p. 226.
} 
como a base do conhecimento, ${ }^{20}$ tal fundamentação, baseada no pensamento de Habermas, sustenta que a legitimidade dos direitos fundamentais é extraída de uma relação dialética entre democracia deliberativa (grosso modo, argumentação pública livre de qualquer coação) e direitos transcendentais: a democracia deliberativa conforma legitimamente os direitos transcendentes, ao passo que tais direitos (e o respeito a tais direitos) garantem a legitimidade do processo democrático. ${ }^{21}$

Sen também formula idéia parecida ao afirmar que os direitos humanos devem ser vistos com demandas éticas abertas ao pluralismo e à discussão pública, pois um escrutínio crítico irrestrito é essencial tanto para a desconsideração quanto para a defesa desses mesmos direitos. ${ }^{22}$ Em outras palavras, quer dizer o economista indiano que a importância (ou mesmo a fundamentalidade) de uma demanda de direitos humanos só pode ser testada através da discussão pública livre.

Configurada a legitimação dos direitos humanos nestes termos, mostra-se incorreto sustentar, portanto, que, por uma questão de "estratégia" de salvaguarda, os direitos sociais não seriam fundamentais. ${ }^{23}$ Demais disso, conjugando-se a forma de legitimação dos direitos humanos acima (demandas éticas politicamente reivindicadas) com a constatação de Sen de que qualquer direito encerra vários tipos de obrigações (tanto obrigações perfeitas quanto imperfeitas, como será visto adiante), parece equivocada a tese de que os direitos sociais (que não envolvem o mínimo existencial) não são fundamentais porque são direitos instituídos no Estado, ao passo que os verdadeiramente fundamentais são somente os direitos pré-estatais $^{24}$ (os de $1^{\text {a }}$ dimensão), para os quais bastaria a abstenção. Difícil imaginar então a fundamentalidade do direito à propriedade ${ }^{25}$ ou até mesmo do direito à liberdade sem qualquer instrumento para sua proteção.

\subsection{Multifuncionalidade e as obrigações dos direitos fundamentais}

Para compreender melhor o problema da crítica dirigida à fundamentalidade (ou não) dos direitos sociais-prestacionais, importante entender a questão das várias obrigações que os direitos fundamentais ensejam (multifuncionalidade),

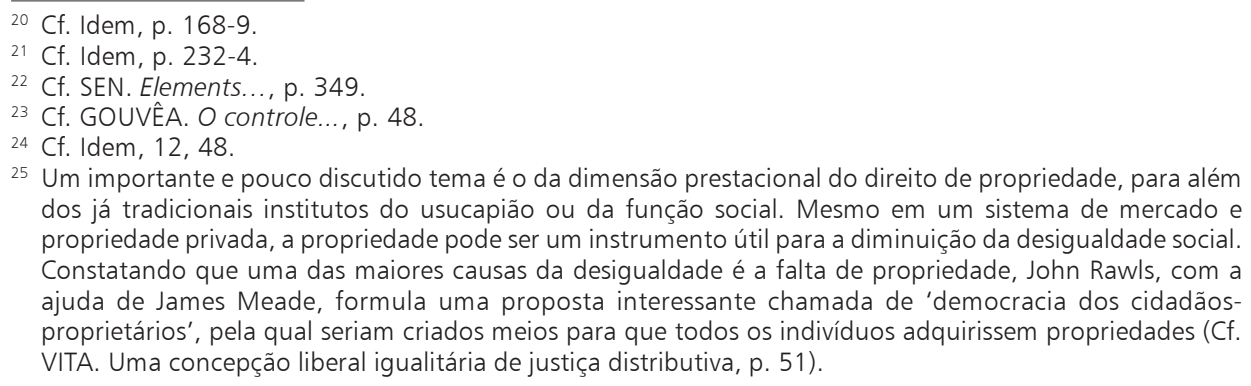

25 Um importante e pouco discutido tema é o da dimensão prestacional do direito de propriedade, para além dos já tradicionais institutos do usucapião ou da função social. Mesmo em um sistema de mercado e propriedade privada, a propriedade pode ser um instrumento útil para a diminuição da desigualdade social. Constatando que uma das maiores causas da desigualdade é a falta de propriedade, John Rawls, com a ajuda de James Meade, formula uma proposta interessante chamada de 'democracia dos cidadãosproprietários', pela qual seriam criados meios para que todos os indivíduos adquirissem propriedades (Cf. VITA. Uma concepção liberal igualitária de justiça distributiva, p. 51). 
com que se faz necessário, inicialmente, tecer algumas observações referentes à classificação dos direitos fundamentais.

São inúmeras as propostas classificatórias dos direitos fundamentais, as quais partem dos mais variados critérios. Interessante para este trabalho é a classificação, sob a perspectiva da função, formulada por Sarlet, tributária das contribuições de Canotilho e, mais remotamente, nas de Jellinek. ${ }^{26}$

Segundo a função preponderante, Sarlet distingue os direitos fundamentais em 'direitos de defesa' (basicamente aqueles ligados ao ideário liberal, direitos de $1^{\text {a }}$ dimensão, tais como vida, liberdade, igualdade formal e propriedade) e 'direitos a prestações'. Nesta última categoria encontram-se os 'direitos a prestações em sentido amplo' (direitos a prestações jurídicas ligadas ao exercício dos direitos de defesa, subdividindo-se em direitos à proteção e em direitos a participação na organização e procedimento) e os 'direitos a prestações em sentido estrito' (direitos a prestações materiais, muitos deles vinculados aos direitos sociais, ou de $2^{a}$ dimensão, tais como educação, saúde, trabalho, etc., os quais voltam-se para o exercício real da liberdade e para a igualdade de fato).$^{27}$

Neste ponto cabe trazer a constatação que faz Sen a respeito da necessidade de se compreender os direitos, quando de sua aplicação, não somente sob o ponto de vista das demandas éticas em si que traduzem, mas também sob o enfoque das obrigações (ou funções) que geram.

A partir dos estudos sobre moral de Kant, Sen apresenta a diferenciação entre 'obrigações perfeitas' (perfect obligations), as quais prescrevem ações específicas, e 'obrigações imperfeitas' (imperfect obligations), caracterizadas por indicarem apenas objetivos gerais. ${ }^{28}$

Note-se que os conceitos de obrigações perfeitas e imperfeitas, utilizados por Sen, relacionam-se com os de 'dimensão negativa' (defesa) ou 'positiva' (prestações) dos direitos fundamentais usados por Sarlet. ${ }^{29}$ Considerando uma obrigação em abstrato, são as omissões (dimensão negativa) o núcleo das perfect obligations,${ }^{30}$ vez que elas sempre se aplicam a todas as situações, e as ações

${ }_{26}$ Cf. SARLET. Op. cit., p. 167-80.

${ }^{27} \mathrm{Cf}$. Idem, p. 178-180, 188-189. Deve-se ficar claro que os direitos sociais não se confundem com os prestacionais. Apesar de muitos direitos sociais serem também prestacionais, alguns possuem nítido caráter defensivo, como a proteção contra despedida arbitrária e proibição de diferença de salário, de exercício de funções e de critério de admissão por motivo de sexo, idade, cor ou estado civil. Ver art. $7^{\circ}, 1$ l XX, Constituiç̧ão da República Federativa do Brasil.

${ }_{28}^{28}$ Cf. SEN. Elements..., p. 346.

29 Cf. SARLET. Op. cit., p. 219. Impende destacar um detalhe importante: Sarlet admite que um direito fundamental pode abranger várias posições jurídicas, de maneira que um direito de defesa pode possuir uma dimensão positiva assim como um direito a prestação pode ter uma dimensão negativa. Sen possui pensamento semelhante, porém parece dar destaque maior ao fato de que a atribuição de vários tipos de obrigações de um direito vai depender dos consenso sociais a este respeito (Cf. Desenvolvimento..., p. 99, 134).

30 Interessante notar o grau de semelhança entre estas obrigações e a 'condição de universalização' do libertarismo. 
(dimensão positiva) o centro das imperfect obligations, porquanto para estas não existe, em princípio, nenhuma regra que indique exatamente como alguém deve agir. Apesar desta distinção, para Sen, ambas as categorias de direitos possuem igual importância, de maneira que não é possível negligenciar a realização das obrigações imperfeitas apenas porque elas não são determináveis em abstrato. ${ }^{31}$

Ato contínuo, Sen argumenta que mesmo os direitos liberais podem gerar um tipo de obrigação que seja imperfeita, ${ }^{32}$ i.e., todos os direitos, sem exceção, prescrevem obrigações tanto perfeitas quanto imperfeitas. É só imaginar, a partir da classificação dos direitos fundamentais acima apresentada por Sarlet, os direitos de defesa clássicos (liberdades diversas (religiosa, de expressão, participação política, etc.), vida, propriedade) sem qualquer prestação em sentido amplo (prestações jurídicas de proteção e de direito de participação na organização e procedimento) ou em sentido estrito (prestações materiais). Sem qualquer violação a tais direitos, parece que eles logram ser usufruídos normalmente, mas e se eles forem violados? Ou se sofrerem ameaça de violação? Logo vê-se que sem outras prestações (obrigações), tais como normativas, para o desestímulo a transgressões normativas, e materiais, como a edificação de aparatos burocráticos representados nas estruturas das funções estatais (legislativa, executiva e judiciária), pouca coisa restaria para a garantia de tais direitos. ${ }^{33}$

\subsection{Sobre o atributo da auto-aplicabilidade dos direitos fundamentais}

Discussão importante para o estudo da fundamentalidade centra-se no atributo da auto-aplicabilidade dos direitos fundamentais. ${ }^{34}$ Para a doutrina, a auto-aplicabilidade é a característica de ser o direito fundamental plenamente aplicável (eficácia plena), sem a necessidade de intermediação legislativa. ${ }^{35}$ Sendo um direito plenamente eficaz, poderia ele ser deduzido em juízo como um direito subjetivo individual, pelo qual o juiz condena um destinatário a uma prestação específica. A partir desta definição, podemos identificar dois problemas relevantes.

O primeiro deles diz respeito à eficácia plena do direito. As seguintes perguntas são inevitáveis: quando um direito é plenamente eficaz? Seria quando fossem plenamente realizáveis todas as obrigações possíveis que dele podem

\footnotetext{
Cf. SEN. Elements..., p. 346.

32 Cf. Idem, p. 346-348.

33 Alerte-se que, com tal argumento, não há intenção de desconsiderar a função importantíssima e intrínseca do reconhecimento, em sua dimensão negativa, dos direitos à vida, à liberdade e à igualdade.

34 Aponta a doutrina os seguintes atributos dos direitos fundamentais: preexistência à ordem jurídica, imprescritibilidade, inalienabilidade, eficácia erga omnes, caráter absoluto e possibilidade de auto-aplicação.

35 Cf. SARLET. Op. cit., p. 263-264.
} 
derivar? Seria possível prever todas as obrigações que um direito pode gerar? Todas estas perguntas parecem difíceis de serem respondidas, mas fica claro que o atributo da auto-aplicabilidade é algo realmente intangível se levarmos em conta a distinção que faz Sen entre direitos e obrigações vista acima. Abstratamente, nenhum direito é plenamente realizável, ainda mais se considerarmos as características das obrigações imperfeitas; ${ }^{36}$ assim, poderíamos dizer apenas que alguma obrigação de um direito seria auto-aplicável, mas não que o próprio direito o seria.

O segundo problema concentra-se em torno de como saber se um direito necessita ou não de interposição legislativa para ser auto-aplicável. Alguns autores entendem que um direito não é auto-aplicável quando a norma que o define expressamente remete a sua concretização ao legislador ${ }^{37}$ ou quando o direito não possui os elementos mínimos necessários para assegurar sua auto-aplicabilidade. ${ }^{38}$ Para Sarlet, de outro lado, a auto-aplicabilidade é somente qualificável no exame do caso concreto. ${ }^{39}$

Não obstante esta ordem de problemas, é possível perceber, ao menos, que a auto-aplicabilidade relaciona-se à possibilidade de definição, minimamente segura, de parte do objeto ou conteúdo do direito (obrigação). Como para a dimensão defensiva dos direitos fundamentais - considerando-se todos eles, sejam classificados como de defesa ou de prestação, segundo sua função preponderante - o objeto sempre é uma omissão, aqui não há nenhuma dificuldade. O problema é a dimensão prestacional dos direitos.

Assinale-se que a doutrina já asseverou que o atributo da auto-aplicabilidade não é um requisito para a fundamentalidade, mas sim o contrário: é a autoaplicabilidade conseqüência da fundamentalidade. ${ }^{40}$ Mas eis que surge uma contradição: reconhecido um direito como fundamental, como atribuir-lhe autoaplicabilidade se, como asseverou Sen, não é possível falar que um direito, em sua integralidade, é auto-aplicável?

Tal fato poderia gerar, no mínimo, uma rediscussão do atributo da autoaplicabilidade. Para a perspectiva subjetiva dos direitos, uma proposta seria admitir

\footnotetext{
${ }^{36}$ Cf. SEN. Elements..., p. 348. Escreve Sen que "se a praticabilidade [feasibility] de se garantir completa e detalhadamente a realização de um direito fosse entendida como uma condição necessária de cogência de todo direito, então não apenas os direitos econômicos e sociais, mas também as liberdades, autonomias e até mesmo os direitos políticos deveriam ficar muito aquém de serem cogentes" (tradução livre, p. 348). ("If the current feasibility of guaranteeing complete and comprehensive fulfillment were made into a necessary condition for the cogency of every right, then not only economic and social rights, but also liberties, autonomies and even political rights may well fall far short of cogency").

37 O que talvez exigiria a interposição de Mandado de Injunção.

38 Cf. SARLET. Op. cit., p. 257.

39 Cf. Idem, p. 264.

${ }^{40}$ Cf. GOUVÊA. O controle..., p. 249.
} 
a garantia de um direito subjetivo individual a partir do atributo da prioridade, derivado principalmente dos princípios do mínimo existencial e da dignidade da pessoa humana, como será visto na seção 2.3.1. Quanto à perspectiva objetiva, vinculada aos direitos sociais inscritos em normas programáticas e afins, uma saída é a proposta de Sen dos meta-direitos, os quais prescrevem obrigações de políticas públicas voltadas para a realização dos direitos, pois, se os direitos não são totalmente auto-aplicáveis, é necessário encontrar um modo de se garantir sua progressiva realização sem a perda de cogência, o que será analisado na seção 3.2.

\section{Direitos sociais e separação dos poderes}

Agora o problema da sindicabilidade dos direitos sociais volta-se aos seus aspectos propriamente jurídicos, ${ }^{41}$ mais especificamente à questão de sua garantia pelo judiciário sem violar o princípio da separação dos poderes. Em outros termos, a intenção desta parte do estudo é encontrar, ao mesmo tempo, os limites da atividade jurisdicional e da discricionariedade estatal (legislativa e executiva) na garantia dos direitos sociais.

Antes do desenvolvimento deste objetivo, cabe apresentar, de maneira sumária, os principais argumentos contrários e favoráveis à sindicabilidade judicial dos direitos sociais.

\subsection{Os argumentos contrários à sindicabilidade judicial dos direitos sociais prestacionais}

Importa consignar, de início, que o fio condutor de todas críticas à sindicabilidade judicial dos direitos sociais é a possível violação do princípio da separação do poderes. ${ }^{42}$

Argumenta-se que por tais direitos envolverem uma infinidade de prestações (objeto ou conteúdo do direito), sua definição legal é sempre genérica. ${ }^{43}$ Como os direitos sociais não apontam, de imediato, para os meios necessários para a sua realização, a definição do seu conteúdo envolveria argumentos de natureza política, sendo os poderes legislativo e executivo os únicos legitimados a realizarem tal tarefa. ${ }^{44}$

\footnotetext{
${ }^{41}$ Assevere-se que outros temas, tais como política e economia, influenciam o debate da sindicabilidade judicial dos direitos sociais. No entanto, apesar de argumentos econômicos e políticos serem importantes em um debate jurídico, nesta seção procurar-se-á demonstrar a importância de se encontrar os limites entre os argumentos jurídicos e outros tipos de argumentos. A preservação do Estado Constitucional de Direito faz-se por meio da garantia do espaço reservado à argumentação e ao ordenamento jurídicos.

42 Cf. SARLET. Op. cit., p. 305.

43 Cf. Idem, p. 321.

${ }^{44}$ Cf. Idem, p. 303-305.
} 
Para muitos, este caráter genérico dos direitos sociais deita razão na suposta imprecisão destas normas, pois elas encerram vários conceitos indeterminados (conceitos técnicos, idéias abstratas, critérios deontológicos), os quais pressupõem juízos subjetivos e discricionariedade por parte do administrador no momento de interpretar e aplicar o direito. ${ }^{45}$

Para outros críticos, a generalidade das normas de direitos sociais é exigência da necessidade de averiguação da realidade fática, sempre contingente, para a escolha das prestações. Contando com corpos técnicos mais aparelhados, o poder executivo é um natural legitimado para praticar juízos de prognose, ou seja, "aqueles cujo preenchimento demanda uma avaliação de pessoas, coisas ou processos sociais $(\ldots) "{ }^{46}$

Pressupondo juízos políticos, a formulação de políticas de realização de direitos sociais só pode ser realizada pelas funções estatais que recebem direta legitimidade do povo: legislativo e executivo; imiscuir-se o judiciário nesta seara teria um componente de violação da vontade popular (dificuldade contramajoritária). Argumenta-se, ademais, que o reconhecimento dos direitos sociais prestacionais diretamente pelo judiciário arrefeceria a participação política do cidadão, pois este não teria que reivindicar do Estado qualquer tipo de política pública. ${ }^{47}$

Vinculada ao argumento da dificuldade contramajoritária está a 'reserva do possível jurídica', a qual traduz-se na impossibilidade do judiciário intrometerse na formulação do orçamento, cuja confecção é atribuição do executivo e do legislativo. ${ }^{48}$

Por fim, há aqueles que opõem aos direitos sociais a 'reserva do possível fática' (limites econômicos), uma vez que estes direitos supostamente demandam vultosos recursos para sua materialização. ${ }^{49}$

Quanto aos argumentos em favor da sindicabilidade dos direitos sociais, são várias suas fontes de inspiração. Alguns deles partem da doutrina administrativista e do controle sobre a discricionariedade da Administração; uns, dos princípios interpretativos constitucionais, notadamente o da máxima efetividade; uns, do primado dos direitos fundamentais; outros dos avanços dos estudos da filosofia e da hermenêutica, principalmente no que toca a discussão em torno da racionalidade das decisões judiciais.

${ }_{45}$ Cf. GOUVÊA. O controle..., p. 62-66; Cf. MORAES. Controle jurisdicional da Administração Pública, p. 73.

${ }^{46}$ MORAES. Op. cit., p. 76.

47 Cf. GOUVÊA. Balizamentos..., p. 342, 361-362. Explicando este argumento, Gouvêa escreve que "[n]a medida em que todas estas posições jurídicas já se encontrassem garantidas, independentemente de qualquer reivindicação política, de nada adiantaria a mobilização popular; retirar-se-ia a importância da cidadania, na medida em que a contemplação dos direitos não seria mais uma questão de conquista da sociedade, mas simples outorga de um Estado (e, especificamente, de um Judiciário) paternalista" (p. 361-362).

${ }^{48}$ Cf. Idem, p. 342.

${ }^{49}$ Cf. SARLET. Op. cit., p. 344. 
Comecemos com mais simples seguindo-se aos mais complexos, de acordo com o grau de complicação apresentada pelas teses que lhe são opostas.

Pois bem. Contra a discricionariedade supostamente permitida pelos conceitos indeterminados, alguns autores entendem que a interpretação e aplicação do direito é sempre uma questão de ordem jurídica, sendo o judiciário legitimado a fazê-lo, através de métodos adequados de hermenêutica. ${ }^{50}$

Sobre a natureza política e subjetiva de vários dos atos administrativos, diz que por mais argumentos políticos que aqueles possam possuir, todos eles contêm também argumentos jurídicos, os quais, portanto, são passíveis de controle. ${ }^{51}$

Também é asseverado que não há discricionariedade plena, pois sempre o Administrador encontra-se vinculado aos limites impostos pela Constituição, pela lei, pelos direitos fundamentais e pelas circunstâncias fáticas. ${ }^{52}$ Por conseguinte, os princípios da moralidade objetiva (isto é, se o ato administrativo realmente atinge o interesse público), da boa-administração (vinculado à eficiência) e da proporcionalidade, bem como o primado dos direitos fundamentais, são importantes limites para a Administração. ${ }^{53}$ Conjugando-se o instrumental de tais princípios com a análise das situações concretas, será possível perceber o grau da liberdade do Administrador, o qual, em determinadas circunstâncias, pode ser nulo (discricionariedade reduzida a zero).$^{54}$

Em oposição à crítica da violação do princípio da separação dos poderes derivada da (suposta) intromissão do judiciário em assuntos de ordem política, há a contribuição das modernas teorias dos direitos fundamentais de Alexy, Dworkin, Habermas, Rawls e Sen, as quais fornecem, em conjunto, elementos éticos, epistemológicos e hermenêuticos para a superação das dificuldades no controle da racionalidade das decisões judiciais que envolvem direitos sociais prestacionais. Em resumo, tais teorias indicam que o critério positivista de legalidade restrita ao texto normativo é insuficiente para resolver os conflitos de uma sociedade cada vez mais plural e complexa, sendo necessária a assimilação

50 Cf. Germana de Oliveira MORAES, Op. cit., p. 74-5. Veja-se ementa do RESP n 493.811/SP, no qual assentouse a possibilidade de exame do ato administrativo discricionário. "ADMINISTRATIVO E PROCESSO CIVIL — AÇÃO CIVIL PÚBLICA — ATO ADMINISTRATIVO DISCRICIONÁRIO: NOVA VISÃO. 1. Na atualidade, o império da lei e o seu controle, a cargo do Judiciário, autoriza que se examinem, inclusive, as razões de conveniência e oportunidade do administrador. 2. Legitimidade do Ministério Público para exigir do Município a execução de política específica, a qual se tornou obrigatória por meio de resolução do Conselho Municipal dos Direitos da Criança e do Adolescente. 3. Tutela específica para que seja incluída no próximo orçamento, a fim de atender a propostas políticas certas e determinadas. 4. Recurso especial provido".

51 Cf. MORAES. Op. cit., p. 165.

52 Cf. Idem, p. 6, 10.

53 Cf. GOUVÊA. Balizamentos..., p. 353-357; Cf. MORAES. Op. cit., p. 170.

54 Cf. MORAES. Op. cit., p. 169-170. Comenta Moraes que "[h]á redução da discricionariedade a zero, quando as circunstâncias normativas e fáticas do caso concreto eliminam a possibilidade de escolha entre diversas opções a ponto de subsistir apenas uma solução juridicamente possível" (p. 169). 
de valores e princípios de justiça. ${ }^{55}$ Porém a assunção do Direito de categorias jurídicas derivadas da ética não necessariamente representa um desvio paro o subjetivismo do discurso jurídico. Muito pelo contrário, admitindo-se que a objetividade plena é inalcançável, pois fruto da metafísica, tais teorias, através da linguagem e do debate democrático, valorizam a racionalidade discursiva democrática - ao invés da verdade - como requisito de validade do conhecimento. ${ }^{56}$

\subsection{Hermenêutica e racionalidade das decisões judiciais — em busca dos limites da atividade jurisdicional e da discricionariedade estatal}

Dos argumentos acima expostos verifica-se que não é tarefa fácil encontrar uma medida exata de equilíbrio entre a defesa jurisdicional dos direitos sociais prestacionais e a discricionariedade estatal na execução destes direitos. De fato, a introdução dos direitos sociais (e seu critério de justiça distributiva) no sistema jurídico de muitas democracias modernas trouxe inúmeras dificuldades para as quais os aparatos jusfilosóficos do liberalismo clássico, fundados em ideais formais de igualdade e liberdade, bem como em critérios de justiça corretiva, não encontram respostas. Demais disso, reforçam tal problema vários outros fenômenos da modernidade, tais como exclusão social, explosão das demandas jurídicas e a ineficácia estatal na efetivação dos direitos. ${ }^{57}$

Diante de tais dificuldades, fica clara a necessidade de se encontrar um modelo de interpretação e aplicação do Direito superador da legalidade positivista, possuindo tal entendimento um caráter ainda muito mais urgente quando observa-se que boa parte dos argumentos ventilados a favor da sindicabilidade judicial dos direitos sociais prestacionais ainda se assenta (em maior ou menor medida) em primados do paradigma jurídico liberal. Assim, tem-se que, por exemplo, não basta opor à discricionariedade estatal simplesmente os princípio da moralidade objetiva, boa administração ou proporcionalidade; faltam ainda requisitos éticos, interpretativos e argumentativos para analisar o conteúdo potencialmente aberto de tais princípios em face das cada vez mais intricadas situações que o judiciário é chamado a intervir. ${ }^{58}$

Neste passo, necessário observar um ponto sumamente importante, o qual retoma a discussão realizada na primeira parte deste trabalho sobre a conflituosidade entre diferentes teorias da justiça — talvez uma das razões para a dificuldade em se equacionar atividade judicial e discricionariedade administrativa.

\footnotetext{
55 Cf. GOUVÊA. O Controle..., op. cit., p. 31, 267-9.

${ }^{56}$ Cf. Idem, p. 168-169; Cf. SEN. Desenvolvimento..., p. 289-311; Cf. VIZARD. Op. cit., p. 46.

57 Cf. RODRIGUES. Liberalismo igualitário: a busca da realização dos direitos e da igualdade, p. 41.

${ }^{58}$ Cf. Marcos Maselli GOUVÊA, O Controle..., op. cit., p. 144; Cf. Daniel dos Santos RODRIGUES. Op. cit., p. 46-49.
} 
De forma lapidar, constata Appio que “[o] debate acerca do conteúdo da Constituição brasileira de 1988 gravita em torno de um tema central: o conflito entre direitos individuais baseados no respeito à vontade humana e uma concepção comum e solidária de justiça" ${ }^{59}$ (grifo nosso).

Tal debate é inescapável e não pode ser continuamente renegado, principalmente porque a defesa política e pragmática de ideais isolados de justiça contestam diuturnamente a legitimidade das decisões judiciais e até mesmo a legitimidade do próprio regime democrático.

Nesses termos, a saída é aprofundar o debate democrático em torno de pontos de equilíbrio entre os ideais de justiça presentes na Constituição, assimilando-os em categoriais jurídicas intersubjetivamente aceitas. ${ }^{60}$ Para a consecução de tal objetivo, o mínimo existencial apresenta-se como um conceito-chave, o qual será apresentado a seguir.

\subsubsection{Mínimo existencial como composição entre os direitos liberais e sociais e como fator de limitação da discricionariedade estatal}

Consiste o mínimo existencial, em apertada síntese, na garantia de condições existências mínimas para a fruição da liberdade individual, tendo origem na doutrina alemã da década de 1950, após com que ganhou impulso com as fundamentações de John Rawls, Jürgen Habermas, Robert Alexy e Amartya Sen.

Através de Habermas, e por meio de seu modelo de fundamentação dos direitos fundamentais baseado na fusão da moral transcendente kantiana e no debate político democrático, o mínimo existencial recebeu maior legitimidade; e em Alexy houve a vinculação do mínimo existencial com o princípio da dignidade da pessoa humana. ${ }^{61}$

De Rawls e Sen o mínimo existencial herdou principalmente a ampliação do ideal de liberdade, o qual, nos dias atuais, passou a conter um conceito material com garantia também das liberdades formais. Em outras palavras, com o liberalismo igualitário de Rawls, deu-se um enorme passo rumo à conciliação entre os ideais formais e materiais de liberdade e igualdade - i.e., entre os direitos liberais e os direitos sociais - e com Sen e a sua 'perspectiva da capacidade' (capability approach), este caminho aprofundou-se. ${ }^{62}$

59 Cf. Eduardo APPIO, Controle Judicial das Políticas Públicas no Brasil, p. 25.

60 Cf. Idem, p. 39-40, 73-40. Destaque-se, neste ponto, a importância de se evitar o uso de argumentos meramente políticos ou filosóficos no discurso jurídico, pois tal atitude, geralmente, é um convite à amplificação do decisionismo judicial e à desqualificação do Estado Democrático de Direito.

61 Cf. GOUVÊA. O Controle..., p. 114, 232-234.

62 Cf. RAWLS. Op. cit., p. 113; RODRIGUES. Op. cit., p. 55-56; Cf. SEN. Desenvolvimento.., p. 95; Cf. VIZARD. Op. cit., p. 13-17. 
Como já afirmado, muito das críticas aos direitos sociais parte da perspectiva equivocada de não se atentar para a importância das oportunidades reais para a fruição da liberdade, separando-se liberdade e justiça. Note-se que com as contribuições dos pensamentos acima, o mínimo existencial faz uma ponte entre os direitos liberais e sociais, demonstra a urgência da realização destes últimos para a consecução da liberdade e apresenta-se como prioridade máxima de um Estado Constitucional.

Portanto, tem-se que, diante da prioridade do mínimo existencial, há um argumento jurídico importante para limitar a discricionariedade estatal na alocação dos recursos públicos.

Demais disso, percebe-se também que o reconhecimento da prioridade do mínimo existencial garante a tal categoria jurídica a possibilidade de constituir-se em um direito subjetivo individual definitivo, conforme aponta Alexy, já que, segundo o exposto na seção 1.3. deste trabalho, a auto-aplicabilidade abstrata não parece ser um atributo suficiente para a geração de um direito subjetivo. Para tal fim, melhor seria realmente utilizar-se de um atributo relacional como o da prioridade, ${ }^{63}$ juntamente com a identificação intersubjetiva de prestações diretamente realizáveis a partir da análise do caso concreto. Neste sentido é que se apresenta a proposta de Alexy, pela qual os direitos fundamentais sociais podem ser mandados jurídico-subjetivos prima facie (restringíveis por fatores jurídicos e fáticos) ou mandados jurídico-subjetivos definitivos (núcleo reforçado, não restringível, quando ligados ao mínimo existencial). ${ }^{64}$ Assim, o mínimo existencial, como mandado definitivo, pode gerar efeitos diretos (e não restringíveis pelo óbice do princípio da separação dos poderes) a partir de uma análise sensível das circunstâncias fáticas e desde que haja razoável consenso na comunidade jurídica - nos moldes do direito construtivo de Dworkin e da democracia deliberativa de Habermas, idéias que serão melhor expostas adiante - a respeito de algumas de suas prestações. ${ }^{65}$

A respeito do conteúdo do mínimo existencial, percebe-se que hoje existe certa divergência. Uns entendem que o princípio deve conter uma lista pré-definida de direitos fundamentais prestacionais e outros argumentam que tal lista deve permanecer aberta. Comentando sobre a escolha de Ana Paula de Barcellos, a qual defende os direitos à educação fundamental, saúde básica, assistência aos desamparados e acesso à justiça como núcleo do mínimo, Sarlet sustenta que um

\footnotetext{
${ }^{63}$ Cf. GOUVÊA. O controle..., p. 49.

${ }^{64}$ Apud SARLET. Op. cit., p. 117-121.

${ }^{65}$ Cf. GOUVÊA. Balizamentos..., p. 370; Cf. SARLET. A eficácia dos direitos fundamentais, p. 346-347.
} 
conteúdo específico não pode ser previamente definido, pois são muitas as prestações possíveis para a promoção de uma vida digna. ${ }^{66}$

Não obstante este pequeno dissenso, necessário reconhecer que uma lista básica aberta de direitos do mínimo existencial pode ser mais eficiente na defesa da dignidade humana. Poder-se-ia argumentar que tal abertura teria o condão de permitir certa discricionariedade e subjetivismo por parte do juiz, mas - como já antecipado acima —, utilizando-se de um controle racional e intersubjetivo sobre a decisão judicial, bem como a partir das especificidades do caso concreto, é possível traçar contenções ao decisionismo jurisdicional. Sendo inevitável certa abertura do sistema jurídico, o que importa destacar é a necessidade de se encontrarem os limites da criatividade hermenêutica, tanto por parte do juiz quanto por parte das outras funções estatais, assunto objeto das próximas seções.

\subsubsection{Justiça corretiva e justiça distributiva — os equívocos em torno do papel da jurisdição}

Desde a concepção do Estado liberal a atividade jurisdicional ainda vinculase a um critério corretivo de justiça (justiça corretiva). Em sua origem, a função precípua da justiça corretiva liberal era restabelecer as partes à condição "normal" e artificial anterior de igualdade e liberdade formais. Como os deveres Estatais resumiam-se a omissões, a tarefa do judiciário em corrigir as violações de tais deveres não encerrava maiores dificuldades. ${ }^{67}$

Com o reconhecimento dos direitos sociais e a introdução dos paradigmas de justiça distributiva a atividade jurisdicional mostrou-se em dúvida a respeito de como deveria se comportar. Afinal, a liberdade e a igualdade agora deveriam ser reais, ou seja, a condição "normal" deveria ser igualdade de oportunidades reais, com que as tarefas estatais multiplicaram-se na perseguição de tais valores.

De fato o poder jurisdicional demonstrou resistência em compreender este novo critério de justiça (distributiva), sendo que a tendência inicial - e que perdura em algum grau nos dias atuais — foi a de negar a defesa judicial dos direitos sociais.

Não obstante a observação de Appio de que a justiça opera “... entre dois senhores, ou seja, entre liberalismo e o intervencionismo do Estado, entre critérios de justiça corretiva e de justiça distributiva", ${ }^{68}$ há que se observar que a resistência da atividade jurisdicional em defender os direitos sociais parte de uma idéia equivocada sobre as funções mesmo que ela deve realizar. Confundiu-se - e ainda

\footnotetext{
${ }^{66}$ Cf. SARLET. Op. cit., p. 346.

67 Cf. RODRIGUES. Op. cit., p. 32-33.

68 Op. cit., p. 59.
} 
confunde-se - a defesa judicial dos direitos sociais com a necessidade do judiciário realizar os meios necessários para sua consecução. Em outras palavras, o fato de existirem agora critérios de justiça distributiva levou muitos a pensar que passouse a exigir do judiciário a realização de tal justiça, o que, de fato, seria uma afronta ao princípio da separação dos poderes.

Cabe aqui a acertada distinção que faz Appio entre as atividades de governo, ligadas às funções legislativa e executiva, e de controle, pertencente à função jurisdicional. Para este autor,

Os órgãos da Função Controladora não governam, apenas controlam de forma independente os atos e omissões dos demais órgãos de Função Constitucional Governativa, no tocante à sua compatibilidade com a Constituição, bem como com os direitos fundamentais do cidadão, função na qual está incluída a jurisdição constitucional, além de assegurar a participação das minorais parlamentares no debate constitucional. ${ }^{69}$

A partir deste pensamento percebe-se, portanto, que controlar a aplicação pelos demais poderes dos critérios de justiça distributiva presentes na Constituição não é uma função ilegítima do judiciário. Muito pelo contrário, coaduna-se perfeitamente com sua função corretiva, desde que o judiciário, chamado a corrigir um desvio ou uma omissão inconstitucionais, não se imiscua na formulação e aplicação da justiça distributiva quando não existirem argumentos racionais e jurídicos para tanto. ${ }^{70}$

Adiante entraremos justamente no debate em torno da busca de instrumentos argumentativos jurídico-racionais para o controle da discricionariedade estatal na realização dos direitos sociais prestacionais.

\subsubsection{Direito versus subjetivismo - a racionalidade do discurso jurídico}

Constata-se que a discussão sobre as ações judiciais que tratam dos direitos prestacionais invariavelmente ultrapassa o âmbito estritamente positivo das normas envolvidas. E isso porque, como já foi observado, a complexidade das demandas sociais e a superação do positivismo fizeram introduzir nos sistemas normativos categorias jurídicas derivadas da ética.

Neste sentido, o que a doutrina contemporânea procurar saber é justamente como lidar com estas novas categoriais jurídicas sem perder objetividade, i.e., sem descambar para o decisionismo ou subjetivismo judicial. Nesta direção estão as propostas formuladas por Dworkin e Habermas, as quais serão aqui apresentadas em seus principais contornos, principalmente a partir dos comentários de Gouvêa e Appio.

\footnotetext{
69 Idem, p. 62.

70 Cf. Idem, p. 67.
} 
Começando com a proposta de Dworkin, deve-se compreendê-la, de início, partindo-se das críticas do autor americano ao positivismo radical de Hart, que pregava a quase total ausência de questões verdadeiramente jurídicas no seio das decisões e discussões judiciais, e à axiologia de Alexy, a qual confundia princípios jurídicos com valores. ${ }^{71}$

Fugindo de ambas as teses, Dworkin compreende o Direito como um sistema deontológico e cultural específico, com objetivos e códigos próprios, o qual não assimila outros argumentos sem antes filtrá-los e transformá-los através de suas próprias categorias. Por conseguinte, entende o autor americano que a função precípua do direito é a busca da integridade, a coerência das decisões judiciais com a tradição jurídica (precedentes jurisdicionais), através de um método interpretativo que nomeia 'construtivo'. Fundamenta-se tal método na idéia de que os princípios jurídicos são ideais transcendentes, os quais representam a composição dos conflitos entre a justiça (dimensão substantiva das decisões políticas) e a eqüidade (dimensão procedimental das decisões políticas) na busca da igualdade, e que através desta composição sedimentam-se e atualizam-se no decorrer da história como padrões de conduta compartilhados por uma determinada comunidade jurídica ou comunidade de princípios. ${ }^{72}$

Nestes termos, tem-se que a racionalidade da ordem jurídica é derivada da coerência do sistema e a legitimidade da intervenção judicial fundada na fiscalização sobre a observância, por parte dos demais poderes, dos princípios jurídicos compartilhados pela comunidade, concepção esta denominada democracia constitucional. ${ }^{73}$

Ao lado da proposta de Dworkin, a teoria discursiva de Habermas também fornece interessantes subsídios para uma maior racionalidade do discurso jurídico. ${ }^{74}$

Possuindo o nome de democracia deliberativa, um dos objetivos da teoria discursiva de Habermas é fornecer ao Direito (e, antes, à política), a partir da ação comunicativa, uma legitimidade baseada no consenso. Assenta-se a ação comunicativa na constatação de que o conhecimento, em verdade, funda-se na linguagem, ou melhor, na relação entre sujeito-sujeito (intersubjetividade, da qual a linguagem é o seu produto) por ocasião de um objeto, e não entre sujeito-objeto. Por conseguinte, o que importa ao conhecimento não é uma suposta verdade (metafísica), mas a sua aceitação pelos membros da comunidade discursiva, cuja argumentação e debate devem estar livres de coação e voltados para

71 Cf. GOUVÊA. O controle..., p. 148-151.

72 Cf. APPIO. Op. cit., p. 32-35; Cf. DWORKIN. Integridade no direito, p. 271-275; Cf. GOUVÊA. O controle..., p. 150-157.

73 Cf. APPIO; Cf. GOUVÊA. O controle..., p. 153, 232.

${ }^{74}$ Cf. GOUVÊA. O controle..., p. 163-166. 
o consenso. ${ }^{75}$ Tem-se, portanto, que tal conceito procedimental de democracia busca, em última análise, “...ampliar o grau de abertura cognitiva do sistema [jurídico], impondo-lhe uma necessidade cada vez maior de heterolegitimação". ${ }^{76}$

Se é improvável estabelecer com plena certeza e objetividade, a partir das normas jurídicas, como exatamente as funções do Estado devem agir, conjugando-se o método construtivo de Dworkin e a democracia deliberativa de Habermas torna-se possível, ao menos, impor algumas balizas e controles sobre as ações e omissões estatais, evitando-se assim uma violação do princípio da separação dos poderes. ${ }^{77}$

Constata-se que certa criatividade e discricionariedade judicial são inevitáveis, porém não devem ser consideradas ilegítimas, pois o que realmente importa é saber os limites desta criatividade - e estes limites, assevere-se, não se resumem ao modelo representativo ou ao princípio majoritário. Ora, democracia é muito mais do que isso e de muito outros ideais retira sua força, como, por exemplo, do Direito e do constitucionalismo, os quais, em conjunto, fornecem controles deontológicos e procedimentais sobre a invariavelmente indócil e arbitrária pragmática política (política como exercício de poder).

Estabelecidas essas premissas, horizontes mais amplos se abrem para a sindicabilidade jurisdicional dos direitos sociais prestacionais. Adiante faremos uma breve incursão a respeito dos aspectos processuais relacionados à defesa judicial dos direitos sociais e, na medida do possível, forneceremos um rascunho de algumas propostas.

\section{Aspectos processuais da defesa judicial dos direitos sociais}

Não cabe neste trabalho uma maior atenção às especificidades processuais e procedimentais da sindicabilidade judicial dos direitos sociais, objeto digno de estudo mais aprofundado. Nada obstante, alguns contornos sobre o assunto merecem apresentação, principalmente no que toca às possíveis ações judiciais e à intervenção judicial no orçamento público.

Note-se que as medidas de sindicabilidade jurisdicional serão exibidas nas perspectivas subjetiva e objetiva dos direitos sociais prestacionais, ${ }^{78}$ sendo que

\footnotetext{
75 Cf. APPIO. Op. cit., p. 37-38; Cf. GOUVÊA. O controle..., p. 168-169; Cf. HABERMAS, Política deliberativa: um conceito procedimental de democracia, p. 19. Para a razão comunicativa, a lingüística tradicional (sintaxe e semântica) possui pouco valor, sendo mais importante a pragmática, voltada aos elementos da comunicação intersubjetiva: "funções da linguagem; que palavras devem ou não ser faladas em cada momento; o cometimento (forma como se transmitem emoções enquanto se fala); o gestual; os sinais gráficos que acompanham o discurso; etc." (Cf. GOUVÊA. O controle..., p. 169).

76 APPIO, p. 40.

77 Cf. GOUVÊA. O controle..., p. 235.

78 Cf. SARLET. Op. cit., p. 151-165. Quanto à perspectiva subjetiva, esta traduz-se na possibilidade do indivíduo impor judicialmente seu direito (individual e não coletivo) perante o destinatário (obrigado). Já a perspectiva
} 
o grau de intervenção judicial em cada um dos casos será abordado de acordo com o potencial de interferência na esfera de discricionariedade das demais funções estatais, atentando-se, por conseguinte, para a não violação do princípio da separação dos poderes.

\subsection{Perspectiva subjetiva - os direitos sociais como direitos subjetivos individuais}

Foi visto que, como mandado jurídico-subjetivo definitivo, o mínimo existencial não admite restrição, pois seu caráter de essencialidade possui prioridade sobre qualquer outra prestação estatal. Assim são, por exemplo, os direitos ligados à saúde básica ou ao ensino fundamental, os quais não podem ser negados sob a justificativa da reserva do possível ou da discricionariedade da administração em realizar o interesse público. ${ }^{79}$

Tem-se que, freqüentemente, tal condição de prioridade do mínimo existencial traduz-se em urgência, sendo necessária uma tutela jurisdicional célere e adequada a se evitar o perecimento do direito do indivíduo. Com efeito, para estes casos traduz-se o mandado de segurança em uma via plausível, uma vez que a Constituição o prescreve para proteger direito líquido e certo “(...) quando o responsável pela ilegalidade ou abuso de poder for autoridade pública ou agente de pessoa jurídica no exercício de atribuições do Poder Público”.

Aqui há que se entender a ilegalidade em um sentido amplo, como qualquer ação ou omissão ilegal ou inconstitucional do Poder Público. Assim, a não prestação ou a prestação defeituosa do mínimo existencial autoriza o indivíduo a demandar o Estado a cumprir o dever de realizar os direitos fundamentais. De outra parte, não há que se falar em dolo ou culpa nem em intervenção indevida sobre a discricionariedade da Administração; o dever estatal sobre o mínimo existencial é objetivo e deriva da própria Constituição, sem contar que, no exame do

objetiva dos direitos fundamentais caracteriza-se, principalmente, por envolver valores objetivos básicos do Estado e dos indivíduos, bem como fins e diretrizes positivas dos poderes públicos. Dentre as várias funções que são derivadas desta perspectiva, interessa-nos as de proteção e de eficácia dirigente, as quais prescrevem ao Estado os deveres de criar condições normativas e, principalmente, materiais para proteger, concretizar e realizar os direitos fundamentais.

79 Note-se que, muitas vezes, os juízes deixam de garantir um direito social levantando-se a reserva do possível sem ao menos considerar as variáveis fáticas e normativas envolvidas. Ouve-se muito o argumento de que a concessão destes direitos pela via judicial poderia provocar problemas sérios nas contas públicas, porém quase nunca percebe-se que o fato do indivíduo ir ao judiciário para defender determinado direito indica, no mais das vezes, a ineficiência estatal em prestar suas obrigações constitucionais. Não é segredo para ninguém que o maior litigante deste país é o Estado, justamente porque é o maior violador da Constituição e das leis. Neste aspecto, Appio apresenta um argumento interessante ao criticar a tese defendida por alguns de que os juízes devem prever os riscos econômicos de suas decisões: na verdade, "...os governos eleitos e os particulares é que, antes de uma opção que confronte com o ordenamento jurídico, devem mensurar de que forma o Poder Judiciário irá reagir em relação ao tema, a partir de uma interpretação coletiva da Constituição" (op. cit., p. 73). 
caso concreto, quase sempre não haverá liberdade do Poder Público em realizar ou não a prestação devida, sendo esta plenamente determinável. Em outras palavras, a prioridade absoluta do mínimo existencial e a sua especificidade no caso concreto quase sempre reduzirá a discricionariedade a zero. ${ }^{80}$

Poder-se-ia levantar a objeção da reserva do possível em face do mínimo existencial como direito individual. Todavia, o argumento não prospera, por algumas razões, a saber. Primeiro, deve-se compreender que a total ausência de recursos é algo realmente muito difícil de ocorrer na prática. Segundo, a objeção da reserva do possível quanto a um demandante individual parece ser pouco razoável. E terceiro, faz-se necessário olhar para a reserva do possível de acordo com as outras verbas do orçamento global, fazendo-se um juízo de prioridade sobre as prestações e programas estatais - e quando fala-se em atendimento do mínimo existencial, nada fica à frente, principalmente em situações que envolvam a vida ou a saúde de um indivíduo. ${ }^{81}$

Cabe registrar, no entanto, que a tutela mandamental encontra um óbice considerável quando da coerção do Poder Público para realizar a decisão judicial. O mandado de segurança, quando concedido, dirige-se ao Estado para que este realize ou não determinado ato, e todos sabem o quanto é difícil coagir alguma autoridade pública a cumprir uma decisão judicial.

Em face da ausência de regras específicas de execução na lei do mandado de segurança, a doutrina, por muito tempo, considerava apenas o crime de desobediência (art. 330, Código Penal) como possibilidade de sanção (indireta, registrese, pois processado em outro juízo) pelo descumprimento da decisão. Não obstante, atualmente existe notícia da utilização da multa como instrumento de coerção no mandado de segurança, aplicando-se o art. 461 do Código de Processo Civil subsidiariamente..$^{82}$

Porém não é difícil perceber que mesmo esta alternativa, no mais das vezes, será inócua contra o Estado. De início verifica-se que, por razão da multa recair sobre o próprio ente estatal, a mora deste poderá ser ainda mais difícil de ser purgada, principalmente se há alguma dificuldade orçamentária. Ocorre também que o ônus da multa quase sempre é repassado às gestões futuras, com o que faz a administração atual pouco ser intimidada por este instrumento coercitivo. ${ }^{83}$

Por tais razões, e em respeito ao princípio da tutela efetiva, há que se preencher a lacuna legislativa no caso concreto através de técnicas que realmente

\footnotetext{
${ }^{80}$ Cf. MORAES. Op. cit., p. 169-170; Cf. GOUVÊA. O controle..., p. 288; Cf. MAURICIO JR., A revisão judicial das escolhas orçamentárias e a efetivação dos direitos fundamentais, item 2.4.

81 Cf. GOUVÊA. Balizamentos..., p. 373-374; Cf. MAURICIO JR., item 6; Cf. SARLET. Op. cit., p. 322; Cf. TORRES. Op. cit., p. 456.

82 Cf. SODRÉ. Mandado de segurança, p. 126-127.

83 Cf. GOUVÊA. O controle..., p. 295.
} 
garantam o direito vindicado. ${ }^{84}$ Neste sentido é o argumento de Gouvêa, o qual, em face da abertura do art. 461 do CPC, defende o uso da sanção de prisão como técnica processual subsidiária de coerção para a realização de prestações materiais pelo ente público. Inspirando-se no êxito da contempt of court do direito americano, pelo qual o juiz intimida o Poder Público devedor a cumprir a decisão judicial proferida nas judicial injunctions, o autor sustenta a constitucionalidade da medida através do princípio da inafastabilidade da jurisdição e da prevalência do direito aos alimentos (obrigação alimentícia presente no art. $5^{\circ}$, LXVII, da Constituição), o qual deve ser interpretado elasticamente como direito fundamental ao mínimo existencial. ${ }^{85}$

Demais disso, é possível também pensar na utilização da lei de improbidade administrativa como instrumento de coerção para o cumprimento da decisão judicial. Tem-se que o art. 11, caput, da Lei $\mathrm{n}^{\circ}$ 8.429/92 prescreve que constitui ato de improbidade administrativa qualquer ação ou omissão que viole o dever de "legalidade". Diz ainda, em seu inciso II, que constitui também ato de improbidade "retardar ou deixar de praticar, indevidamente, ato de ofício". Sabendo-se que o conceito de legalidade é muito mais amplo do que a letra fria de lei, não é necessário fazer grande esforço de interpretação para perceber que tais prescrições podem perfeitamente amoldar-se às situações de descumprimento de uma decisão judicial, ainda mais quando determinam a realização de prioridades constitucionais já normativamente previstas e derivadas do mínimo existencial.

Apesar de ser um meio indireto de intimidação, já que a verificação do cometimento de ato de improbidade ocorre em processo distinto e após um juízo a respeito da pertinência da ação por parte do Ministério Público (autor mais freqüente destas demandas), a Lei $n^{\circ} 8.429 / 92$ possui sanções severas, tais como perda da função pública e suspensão dos direitos políticos, cuja menção pode ser suficiente para induzir o devedor a cumprir a decisão.

Não vinculados ao mínimo existencial, os direitos sociais prestacionais ou melhor, determinadas prestações ligadas a estes direitos — podem ser mandados

\footnotetext{
${ }^{84}$ Cf. MARINONI. A legitimidade da atuação do juiz a partir do direito fundamental à tutela jurisdicional efetiva, item 3. "Como esse direito fundamental [à tutela jurisdicional efetiva] incide sobre o Estado e, portanto, sobre o legislador e o juiz, é evidente que a omissão do legislador não justifica a omissão do juiz. Melhor explicando: se tal direito fundamental, para ser realizado, exige que o juiz esteja munido de poder suficiente para a proteção — ou tutela — dos direitos, a ausência de regra processual instituidora de instrumento processual idôneo para tanto constitui evidente obstáculo à atuação da jurisdição e ao direito fundamental à tutela jurisdicional. Diante disso, para que a jurisdição possa exercer a sua missão — que é tutelar os direitos - e para que o cidadão realmente possa ter garantido o seu direito fundamental à tutela jurisdicional, não há outra alternativa a não ser admitir ao juiz a supressão da omissão inconstitucional".

${ }^{85}$ Cf. GOUVÊA. O controle..., p. 298-300. Segundo esta proposta, e em respeito ao parágrafo $4^{\circ}$ do art. 461 do Código de Processo Civil, o juiz deverá, de início, avaliar no caso concreto se a multa é suficiente e compatível para a garantia do direito; não o sendo, aí poder-se-á utilizar da prisão como sanção do eventual descumprimento da decisão judicial.
} 
jurídico-subjetivos prima facie, i.e., restringíveis segundo a discricionariedade estatal, já que não possuem caráter prioritário para o indivíduo em termos imediatos. Nestes termos, tem a Administração maior discricionariedade na realização destes direitos sociais prestacionais, sendo o controle jurisdicional sobre as escolhas e omissões administrativas mais fraco, ${ }^{86}$ reservando-se apenas a verificar algumas condições fáticas, técnicas e normativas, tais como: a existência de equívoco das premissas adotadas pelo Poder Público para a tomada da decisão (motivo falso); se há desrespeito ao principio da igualdade, quando o administrador pretere grupos ou pessoas de determinadas prestações $;{ }^{87}$ se existe algum direito derivado à prestação (obrigatoriedade legal), sendo que, inexistente, o Estado tem alguma liberdade na maneira de realizar a prestação invocada; se há conflito com algum outro direito fundamental; etc.

Seriam exemplos de prestações individuais não prioritárias ligadas aos direitos sociais fundamentais prestacionais a de ter um emprego (direito ao trabalho) ou a de ter uma casa (direito à moradia). Os direitos ligados a estas prestações são fundamentais, sem dúvida, mas não podem ser opostos individualmente ao Poder Público em sua máxima extensão, sem qualquer restrição e sem violar frontalmente o princípio constitucional da livre iniciativa. Em outros termos, evitar um Estado irresponsável e omisso não pode corresponder a erigir um outro caridoso e paternalista.

Adiante será visto que, apesar de ser aparentemente impossível, por exemplo, fornecer um emprego ao indivíduo, é razoável exigir do Estado alguma política, minimamente eficaz, voltada à criação de empregos. Tal seria a perspectiva objetiva dos direitos fundamentais, as quais envolvem, no mais das vezes, pretensões coletivas e/ou difusas, como será melhor observado.

\subsection{Perspectiva objetiva - os direitos sociais como direitos coletivos}

Através da perspectiva objetiva dos direitos fundamentais é possível perceber que estes direitos também podem encerrar deveres objetivos mais amplos a serem cumpridos pelo Estado. É neste sentido que se encontra a proposta dos meta-direitos de Amartya Sen, pela qual o Estado possui o dever de promover políticas públicas minimamente eficazes para a realização dos direitos fundamentais. Sen justifica a categoria a partir da constatação de que é impossível garantir, de imediato, determinadas prestações de um direito; ${ }^{88}$ e ao compreender os direitos como prestações graduais, i.e., não em termos de tudo ou nada, menores

\footnotetext{
${ }^{86}$ Cf. MAURICIO JR., Op. cit., item 3.

${ }^{87} \mathrm{Cf}$. Idem, item 2.

${ }^{88}$ Sobre as várias obrigações que os direitos podem possuir, cf. seção 1.2.
} 
são as chances de contestação do sistema jurídico-político quando tais direitos não são garantidos em sua integralidade. ${ }^{89}$

Ato contínuo, como um dos objetivos deste trabalho é encontrar um controle jurisdicional garantidor dos direitos fundamentais que não viole o princípio da separação dos poderes, cumpre identificar as variáveis que vinculam o Administrador à consecução destes meta-direitos, sendo elas basicamente duas: o grau de detalhamento normativo das políticas públicas e a vinculação das verbas orçamentárias.

Partindo-se de um grau forte de vinculação, podemos falar da hipótese na qual as políticas públicas, apesar de já definidas e incluídas no orçamento (existência de dotação), não são implementadas. Dentre as razões da não implementação, destacam-se três: “a) problemas de "dinheiro", decorrentes da falta de arrecadação dos ingressos previstos nas leis orçamentárias; b) problemas técnicos para o fornecimento da prestação; e c) exercício do poder discricionário administrativo no contingenciamento de recursos". ${ }^{90}$

Sobre os problemas de "dinheiro", tem-se que a questão transfere-se para as prioridades de realocação de verbas no orçamento, sendo duas as hipóteses que autorizam a revisão judicial: a) prestações ligadas ao mínimo existencial; b) existência de decisões prévias sobre prioridades orçamentárias, principalmente se estão já definidas nas leis do Plano Plurianual (PPA) e de Diretrizes Orçamentárias (LDO).$^{91}$

Com relação aos problemas de ordem técnica que podem impedir a execução de uma prestação, poderá haver revisão judicial se existir evidente equívoco, verificado por dilação probatória, nas premissas adotadas pelo administrador para a adoção de uma decisão de não fornecimento da referida prestação. Se as premissas forem inconclusivas, i.e., se não for possível dizer com certeza se houve erro na tomada da decisão administrativa, o administrador possui discricionariedade. ${ }^{92}$

Quanto ao contingenciamento de recursos, executado por simples decisão discricionária da Administração, é possível a revisão judicial em duas situações:

\footnotetext{
Cf. SEN. El Derecho a no Tener Hambre, p. 16-17.

90 MAURICIO JR. Op. cit., item 8.2.

91 Cf. Idem, loc. cit.

92 Cf. Idem, loc. cit. Mauricio Jr. fornece o exemplo do Mandado de Segurança n. 8.895/DF, impetrado no STF contra o Ministro da Saúde. Escreve o autor que "o impetrante, portador de anomalia degenerativa da retina (retinose pigmentar) requeria que o seu tratamento no exterior fosse custeado pelo Estado. O pedido foi indeferido porque não havia certeza do equívoco das premissas administrativas. Ao contrário, segundo parecer do Conselho Brasileiro de Oftalmologia, a doença em questão era de origem hereditária e não havia comprovação científica quanto à eficácia dos tratamentos clínicos ou cirúrgicos requeridos pelo impetrante" (Apud item 8.2).
} 
a) se o ato violar o princípio da igualdade, i.e., se preterir grupos ou pessoas determinadas; b) se não houver justificativa razoável para medida, ou seja, quando as prestações preteridas demonstrarem serem prioritárias (principalmente as relacionadas aos direitos fundamentais) em relação a outras prestações contidas no orçamento. ${ }^{93}$

Como grau médio de vinculação, há a situação na qual, não obstante a existência de previsão legal, as políticas públicas não são incluídas no orçamento; não existe verba ou dotação orçamentária, porém existem leis que exigem a realização de determinados programas ou prestações (sem reservar percentuais do orçamento). Neste caso, o judiciário pode condenar o Executivo a realocar os recursos no orçamento para a realização do programa, uma vez que trata-se de exigência explicitamente determinada em lei. ${ }^{94}$

Por fim, como grau fraco de vinculação, tem-se o caso mais complexo, qual seja, o da inexistência de políticas públicas específicas, havendo tão-somente previsões constitucionais e/ou legais genéricas da alocação de verbas para os direitos respectivos, como, por exemplo, os deveres de aplicação de percentuais orçamentários aos direitos à seguridade social, à saúde e à educação. ${ }^{95}$

Primeiramente, como tais verbas constituem prioridades constitucionais e legais vinculadas ao mínimo existencial, ocorrendo violação quanto à aplicação do dinheiro público, é certo que o judiciário pode intervir para corrigir tal vício de destinação. ${ }^{96}$

Pode acontecer, no entanto, que, mesmo sendo aplicados os percentuais prescritos normativamente, as políticas públicas correspondentes podem demonstrar serem ineficazes ou as verbas aplicadas podem ser insuficientes. ${ }^{97}$ Partindo-se da prioridade dos direitos fundamentais e do princípio da eficiência, assim como constatando-se no processo a ausência de políticas eficazes ou que a política aplicada é ineficaz, ao judiciário é autorizado determinar ao administrador a realocação de recursos orçamentários e a confecção de algum plano de realização do direito social respectivo. ${ }^{98}$

Nos termos expostos acima, tem-se que, avaliando-se o orçamento em sua totalidade e observando-se as prescrições normativas quanto à vinculação a políticas e reservas orçamentárias, é possível defender uma intervenção jurisdicional

\footnotetext{
93 Cf. Idem, loc. cit.

94 Cf. Idem, item 8.3.

95 Pertinente a observação que faz Scaff sobre a malfadada Desvinculação das Receitas da União (DRU). Diz o autor que, diante da prioridade do mínimo existencial, a DRU fatalmente configura-se como inconstitucional (Cf. SCAFF. Reserva do Possível, o mínimo existencial e direitos humanos, p. 157).

96 Cf. MAURICIO JR. Op. cit., item 8.1.

97 Cf. SARLET. Op. cit., p. 349; Cf. Alceu MAURICIO JR., op. cit., item. 6.

98 Cf. GOUVÊA, O controle..., p. 306-310; Cf. MAURICIO JR. Op. cit., item. 8.3.
} 
indireta no orçamento, na qual, mantendo-se a liberdade da Administração para reorganizar a peça orçamentária, o juiz apenas indicaria a prioridade constitucional a ser atendida. Note-se que tal solução respeita a reserva do possível e a discricionariedade do administrador, sem, contudo, descurar da defesa dos direitos fundamentais. ${ }^{99}$

Importa registrar que as propostas expostas acima são em grande parte derivadas das experiências jurídicas dos Estados Unidos e da África do Sul.

Nos exemplos norte-americanos das structural injunctions - imposições de previsão orçamentária de recursos para a realização de prestações, as quais foram largamente utilizadas nos casos que reformaram o sistema prisional, os hospitais psiquiátricos e o sistema educacional do país —, raramente o judiciário fazia ingerências diretas no orçamento. A partir da comprovação da ilegalidade das ações ou omissões, geralmente os juízes sugeriam medidas para a solução dos problemas. "A partir daí, a própria Administração, incorporando estas sugestões, formulava um plano que, após aprovação do magistrado, era implementado sob a supervisão de um staff nomeado pelo juiz". ${ }^{100}$

Quanto aos exemplos da jurisprudência sul-africana, em uma série de históricos julgamentos a Corte Constitucional do país assentou que a reserva do possível não pode ser oposta à obrigação constitucional do governo criar medidas e programas razoáveis para a progressiva realização dos direitos fundamentais sociais. ${ }^{101}$ No caso mais famoso, Grootboom and others vs Government of Republic of South Africa, no qual demandava-se o direito à residência adequada, a Corte não determinou quais prestações deveriam ser fornecidas e como seriam fornecidas, porém impôs a realocação de verbas do orçamento da habitação, deixando a implementação específica “...a cargo das autoridades administrativas, a quem em primeira instancia incumbe tratar dessas questões". ${ }^{102}$

Ao contrário do que muitos podem imaginar, a intervenção judicial na alocação de verbas na peça orçamentária não é estranha ao direito brasileiro. De fato, a ordem de inclusão de verba para alguma política no orçamento é análoga à expedição de um precatório judicial, só que com um detalhe: o destinatário do título não é um sujeito em particular, mas sim a própria sociedade. ${ }^{103}$

\footnotetext{
99 Cf. GOUVÊA. O controle...; Cf. MAURICIO JR., Op. cit., item 6.

100 GOUVÊA. O controle..., p. 306.

101 Cf. VIZARD. Op. cit., p. 24-25.

102 MAURICIO JR. Op. cit., item. 5.

103 Cf. MAURICIO JR. Op. cit., itens 6 e 7. Observe-se que não parece correto o argumento de Gouvêa ao escrever que a inclusão de rubrica no orçamento seria como uma expedição de um precatório em favor do próprio Estado. Não é o Estado o destinatário da política, mas sim a sociedade, uma vez que as políticas vinculadas no orçamento têm como finalidade a realização dos direitos fundamentais e do interesse público. Aqui talvez tenha acontecido a confusão, muito comum na doutrina nacional, entre a esfera pública e o
} 
Como direito a políticas públicas, e sabendo-se que não existem direitos prima facie coletivos, difusos ou individuais homogêneos, ${ }^{104}$ um meta-direito caracteriza-se perfeitamente como uma pretensão coletiva lato sensu, sendo possível sindicá-lo judicialmente através de ação civil pública. Sobre esta ação, a observação mais importante que aqui cumpre fazer é quanto à forma de execução de sua sentença, uma vez que, em sua fase de conhecimento, não há nada que a faça muito diferente de uma pretensão coletiva qualquer.

Ato contínuo, com a constatação da necessidade de implementação progressiva dos direitos sociais prestacionais, tem-se que deve ser fortemente revista a idéia da processualística liberal clássica de que o processo deve extinguir-se no menor prazo possível. ${ }^{105}$ Aprovado o plano de realização da política pública (o qual fará parte da sentença), a execução da decisão irá se dilatar no tempo, de maneira que sua fiscalização obrigará do juiz maior participação. Uma execução como esta pode causar certa estranheza aos nossos juízes, visto que acostumados ainda à defesa de direitos eminentemente patrimoniais e de defesa. No entanto, a complexidade social e a demanda pelos direitos sociais são fenômenos inevitáveis, os quais obrigam os juristas a encontrar novas alternativas para dar efetividade aos direitos.

\subsection{Conclusões sobre a utilização do mandado de segurança e da ação civil pública na defesa dos direitos sociais prestacionais}

Por fim, cabe comentar a necessidade de haver intenso rigor deontológico e dialógico nas ações que tenham por finalidade a realização do mínimo existencial e de políticas públicas. Como tais demandas envolvem inúmeras variáveis normativas e fáticas, cabe aqui perfeitamente o aviso das teorias dworkniana e habermasiana. No que concerne à defesa do mínimo existência, avulta-se o caráter principiológico das situações que se apresentam, com o que se exige disciplina do sistema jurisdicional em encontrar e preservar os princípios jurídicos da sociedade. Quanto às demandas de políticas públicas, revela-se importante o debate democrático para a busca de consensos e decisões judiciais legítimas, de maneira que as funções estatais não ultrapassem seus limites constitucionais e assim seja preservado certo equilíbrio institucional sem se desviar da defesa dos direitos fundamentais.

Estado. Apesar do ente estatal perseguir o interesse público, este não é propriedade daquele, mas sim propriedade da sociedade (O controle..., p. 314).

104 Como observa Gouvêa, "[e]m regra, não existem direitos prima facie difusos, coletivos ou individuais homogêneos; é analisando o pedido formulado na ação civil pública que se poderá afirmar a existência de uma pretensão difusa, coletiva ou individual homogênea, ou demais de uma destas classes em cumulação" (O controle..., p. 332).

105 Cf. MAURICIO JR. Op. cit., item 1. 
Deve-se registrar que, pelas limitações deste trabalho, muitas questões ainda estão em aberto e merecem estudo pormenorizado. Assim são, por exemplo, os detalhes e especificidades das fases de execução das decisões em mandado de segurança, quando em defesa do mínimo existencial, e das sentenças em ação civil pública, quando tenham como objeto a realização de política pública.

Demais disso, deve haver também estudo futuro sobre o uso do Mandado de Injunção nos casos de demandas de políticas públicas. A princípio parece ser difícil utilizar o instrumento para se cobrarem prestações materiais - mesmo que haja expressa remissão à necessidade de intervenção legislativa para a aplicação da norma —, vez que sua finalidade afina-se mais à supressão de omissões normativas genéricas. ${ }^{106}$ De outra parte, a utilização do rito do mandado de segurança para as ações em Mandado de Injunção parece ser inadequada para a sindicabilidade de políticas públicas. ${ }^{107}$

São dúvidas que devem ser melhor apreciadas em pesquisas posteriores.

\section{Conclusão}

A primeira parte do artigo dedicou-se principalmente à discussão da fundamentalidade (ou não) dos direitos sociais. Apontou-se, a partir dos estudos de Sen, para o fato de que os direitos fundamentais guardam em si concepções diferentes de justiça, as quais, muitas vezes, entram em conflito, de maneira que não parece possível, a partir de um ponto de vista ético isolado, dizer que alguns direitos não seriam fundamentais. Constatou-se que os direitos são fundamentais não por escolhas arbitrárias, mas sim porque reconhecidos a partir de uma conjugação entre a ética e a deliberação democrática. Por fim, foi estudada também a multifuncionalidade dos direitos fundamentais, uma vez que eles podem ensejar vários tipos de posições e obrigações jurídicas, detalhe que denuncia a impossibilidade de ser um direito - seja de qualquer tipo plenamente auto-aplicável.

Na segunda parte discutiu-se a possibilidade (ou não) da defesa judicial dos direitos sociais ofender o princípio da separação dos poderes, principalmente pelo fato de tais demandas encerrarem elementos éticos e políticos, bem como conflitos entre direitos e princípios jurídicos, o que seria uma porta aberta ao subjetivismo (decisionismo) judicial. Neste ponto foi feita uma apresentação dos principiais argumentos favoráveis e contrários à sindicabilidade judicial dos direitos sociais, de maneira que, em seguida, fosse possível propor requisitos filosóficos e argumentativos para se superar a legalidade positivista — insuficiente

\footnotetext{
${ }^{106}$ Cf GOUVÊA. O controle..., p. 315; Cf. MAURICIO JR. Op. cit., item 8.3.

107 Cf. MAZZEI. Mandado de injunção, p. 137-138.
} 
para lidar com as complexas demandas destes direitos - e para se equilibrarem os conflitos entre os ideais de justiça dos direitos liberais e sociais. Para o primeiro objetivo, foram comentadas as propostas do direito construtivo de Dworkin e da democracia deliberativa de Habermas; para o último, foi discutida a teoria do mínimo existencial, valendo-se, principalmente, da concepção de liberdade de Sen.

Ao final do estudo, foram tratados os aspectos processuais da defesa judicial dos direitos sociais. Verificou-se que, com o intuito de equilibrar mecanismos de garantia dos direitos e contenção da atividade jurisdicional, algumas medidas processuais, tais como o mandado de segurança e a ação civil pública, se devidamente adaptadas de acordo com o princípio fundamental à tutela jurisdicional efetiva, podem ser utilizadas para a realização dos direitos sociais prestacionais. Sobrelevaram-se, neste ponto, a concepção de mínimo existencial como direito subjetivo individual definitivo de Alexy, cuja defesa não pode ser oposta pela reserva do possível e pelo princípio da separação dos poderes, e o conceito de metadireitos de Sen, pelo qual poder-se-á exigir do Estado a realização progressiva dos direitos sociais a partir da concretização de políticas públicas.

Por fim, deve-se asseverar que o assunto é muito mais complexo do que este pequeno texto poderia abarcar. De fato, o problema da defesa judicial dos direitos sociais prestacionais envolve estudos das mais variadas áreas do conhecimento humano para além do direito (tais como ciência política, economia, sociologia, etc.), de maneira que se procurou abordar aqui aspectos mais introdutórios do tema, principalmente com relação à hermenêutica e à filosofia ética.

\begin{abstract}
This article studies, from the referential of the of Amartya Sen's theory of human rights, the obstacles and possibilities to the judicial defense of the positive social rights. It observes that the fulfillment of these rights faces three main orders of problems: 1) philosophical, because partial theories of justice contest its fundamental status; 2) legal-political, since, by involving complex normative and material obligations, as well as ethical and political arguments, the fulfillment of the positive social rights by the jurisdiction could violate the principle of the separation of powers; 3) legalprocedural, because the current procedural instruments are insufficient and jurisprudence experiences are relatively new. It is concluded that, despite such difficulties, the fulfillment of the positive social rights is possible if the basic rights are recognized from a combination between plural ethical judgments and democratic deliberation. Furthermore, using interpretative, argumentative and broad ethical instruments, such as the constructive law of Dworkin and the deliberative democracy of Habermas, as well as the principle of the existential minimum, the judiciary power would be able to defend the positive social rights without violating the principle of the separation of powers. Finally, using the concepts of existential minimum
\end{abstract}


and meta-rights, the judicial defense of the positive social rights can take place through some procedural current instruments, provided that properly used according to the principle of effective judicial protection.

Keywords: Fundamental Rights. Positive Social Rights. Administrative Discretion. Effectiveness of Rights. Violation of the Separation of Powers.

\section{Referências}

ALEXANDER, John M. Capabilities, human rights and moral pluralism. The International Journal of Human Rights, v. 8. n. 4, part of the Taylor \& Francis Group, Winter 2004. p. 451-469. Disponível em: < http://www.unipv.it/deontica/sen/papers/Alexander.pdf > . Acesso em: 30 jun. 2007.

APPIO, Eduardo. Controle judicial das políticas públicas no Brasil. 1. ed. 4. reimpressão (ano 2007). Curitiba: Juruá, 2005.

BONAVIDES, Paulo. A teoria dos direitos fundamentais. In: BONAVIDES, Paulo. Curso de direito constitucional. 13. ed. São Paulo: Malheiros, 2003. p. 560-578.

BRASIL. Código de Processo Civil. Lei n. 5.869, de 11 de janeiro de 1973. Institui o Código de Processo Civil. Disponível em: < http://www.planalto.gov.br/ccivil_03/LEIS/ L5869.htm >. Acesso em: 17 dez. 2007.

BRASIL. Constituição da República Federativa do Brasil de 1988. Disponível em: <http:// www.planalto.gov.br/ccivil_03/Constituicao/Constituiçao.htm>. Acesso em: 28 nov. 2007.

BRASIL. Lei n. 1.533, de 31 de dezembro de 1951. Altera disposições do Código do Processo Civil, relativas ao mandado de segurança. Disponível em: < http://www.planalto.gov.br/ ccivil_03/LEIS/L1533.htm>. Acesso em: 17 dez. 2007.

BRASIL. Lei n. 7.347, de 24 de julho de 1985. Disciplina a ação civil pública de responsabilidade por danos causados ao meio-ambiente, ao consumidor, a bens e direitos de valor artístico, estético, histórico, turístico e paisagístico (VETADO) e dá outras providências. Disponível em: <http://www.planalto.gov.br/ccivil_03/Leis/L7347orig.htm>. Acesso em: 10 dez. 2007.

BRASIL. Lei n. 8.429/92, de 2 de junho e 1992. Dispõe sobre as sanções aplicáveis aos agentes públicos nos casos de enriquecimento ilícito no exercício de mandato, cargo, emprego ou função na administração pública direta, indireta ou fundacional e dá outras providências. Disponível em: < http://www.planalto.gov.br/ccivil_03/Leis/L8429.htm>. Acesso em: 10 dez. 2007.

BRASIL. STJ. RESP n. 493.811/SP. Rel. Min. Eliana Calmon. Decisão em 11.01.2003. Publicado em DJ 15.03.2004, p. 236. Disponível em: <http://www.stj.gov.br/SCON/ jurisprudencia/toc.jsp?tipo_visualizacao $=$ RESUMO\&processo $=493811 \& \mathrm{~b}=\mathrm{ACOR}>$. Acesso em: 5 jan. 2008.

DWORKIN, Ronald. Integridade no Direito. In: DWORKIN, Ronald. O império do direito. Tradução de Jefferson Luiz Camargo, revisão Técnica de Gildo Sá Leitão Rios. São Paulo: Martins Fontes, 2003. p. 271-331.

GOUVÊA, Marco Maselli. Balizamentos da discricionariedade administrativa na implementação dos direitos econômicos, sociais e culturais. In: GARCIA, Emerson (Coord.). Discricionariedade administrativa. Rio de Janeiro: Lumen Juris, 2005. p. 309-386. 
GOUVÊA, Marco Maselli. O controle judicial das omissões administrativas: novas perspectivas de implementação dos direitos prestacionais. Rio de Janeiro: Forense, 2003.

HABERMAS, Jürgen. Política deliberativa: um conceito procedimental de democracia. In: HABERMAS, Jürgen. Direito e democracia: entre facticidade e validade. Tradução de Flávio Beno Siebeneichler. 2. ed. Rio de Janeiro: Tempo Brasileiro, v. 2, p. 9-56.

MACEDO JÚNIOR, Ronaldo Porto. Ação civil pública, o direito social e os princípios. In: MILARÉ, Édis (Coord.). A Ação Civil Pública após 20 anos: efetividade e desafios. São Paulo: Revista dos Tribunais, 2005. p. 290-299.

MARINONI, Luis Guilherme. A legitimidade da atuação do Juiz a partir do direito fundamental à tutela jurisdicional efetiva. Não paginado. Disponível em: < http://www.professor marinoni.com.br/principal/pub/anexos/20080129021320A_LEGITIMIDADE_DA_ ATUACAO_DO_JUIZ_A_PARTIR_DO_DIREITO.pdf>. Acesso em: 6 jan. 2008.

MAURICIO JR., Alceu. A revisão judicial das escolhas orçamentárias e a efetivação dos direitos fundamentais. Revista Diálogo Jurídico, Salvador, n. 15, jan./mar. 2007. Não paginado. Disponível em: <http://www.direitopublico.com.br/pdf/Revisao_Judicial_ Escolhas.pdf $>$. Acesso em: 7 jul. 2007.

MAZZEI, Rodrigo. Mandado de Injunção. In: DIDIER JR., Fredie (Org.). Ações constitucionais. 2. ed. Salvador: JusPodivm, 2006. p. 135-196.

MORAES, Germana de Oliveira. Controle jurisdicional da Administração Pública. 2. ed. São Paulo: Dialética, 2004.

RAWLS, John. Uma teoria da justiça. Tradução Almiro Pisetta e Lenita Maria Rímoli Esteves. 2. ed. São Paulo: Martins Fontes, 2002.

RODRIGUES, Daniel dos Santos. Liberalismo igualitário: a busca da realização dos direitos e da igualdade. Monografia (Conclusão do Gurso de Graduação em Direito) - Faculdade de Direito/UFG, Goiânia, 2005.

SARLET, Ingo Wolfgang. A eficácia dos direitos fundamentais. 4. ed. Porto Alegre: Livraria do Advogado, 2004.

SCAFF, Fernando Facury. Reserva do possível, mínimo existencial e direitos humanos. In: COUTINHO, Jacinto Nelson de Miranda; LIMA, Martorio Mont'Alverne Barreto (Org.). Diálogos constitucionais: direito, neoliberalismo e desenvolvimento em países periféricos. Rio de Janeiro: Renovar, 2006. p. 145-162.

SEN, Amartya Kumar. Desenvolvimento como liberdade. Tradução Laura Teixeira Motta. Revisão técnica Ricardo Doniselli Mendes. 1. ed. 6. reimpressão (ano 2007). São Paulo: Companhia das Letras, 2000.

SEN, Amartya Kumar. Elements of a Theory of Human Rights. Philosophy and Public Affairs, 32, 4, Fall 2004; Research Library Core, p. 315-356. Disponível em: < http://www.mit.edu/ $\sim$ shaslang/mprg/asenETHR.pdf >. Acesso em: 16 set. 2007.

SEN, Amartya Kumar. El Derecho a no Tener Hambre. Traducción de Everaldo Lamprea Montealegre, Estudios de Filosofia y Derecho n. 3 (Teoria de Los Derechos), Universidad Externado de Colômbia, Centro de Investigación en Filosofia y Derecho, Bogotá, 2002.

SODRÉ, Eduardo. Mandado de segurança. In: DIDIER JR., Fredie (Org.). Ações constitucionais. 2. ed. Salvador: JusPodivm, 2006. p. 89-134. 
TORRES, Ricardo Lobo. O mínimo existencial, os direitos sociais e a reserva do possível. In: COUTINHO, Jacinto Nelson de Miranda; NUNES, António José Avelãs (Org.). Diálogos constitucionais: Brasil/Portugal. Rio de Janeiro: Renovar, 2004. p. 447-471.

VITA, Álvaro de. Uma concepção liberal igualitária de justiça distributiva. Revista Brasileira de Ciências Sociais, v. 14, n. 39, p. 41-59, fev. 1999. Disponível em: <http://www.scielo.br/ cgi-bin/fbpe/fbtext?got $=$ last\&pid $=$ S010269091999000100003\&l ng $=$ en\&nrm $=$ iso $>$. Acesso em: 10 mar. 2005.

VIZARD, Polly. The Contributions of Professor Amartya Sen in the Field of Human Rights. CASEpaper 91. London: Centre for Analysis of Social Exclusion, London School of Economics, 2005. Disponível em: <http://sticerd.lse.ac.uk/dps/case/cp/CASEpaper91.pdf>. Acesso em: 30 jun. 2007.

Informação bibliográfica deste texto, conforme a NBR 6023:2002 da Associação Brasileira de Normas Técnicas (ABNT):

RODRIGUES, Daniel dos Santos. A defesa judicial dos direitos sociais prestacionais a partir da teoria dos direitos humanos de Amartya Sen. A\&C-Revista de Direito Administrativo e Constitucional, Belo Horizonte, ano 8, n. 34, p. 107-139, out./dez. 2008. 